\title{
PERLINDUNGAN HUKUM TERHADAP ISTERI YANG MENJADI KORBAN KEKERASAN DALAM RUMAH TANGGA OLEH SUAMI
}

\author{
Bambang Sutrisno ${ }^{1}$, Siti Asmaul Husna ${ }^{2}$ \\ 1. Universitas Islam Kadiri, Kediri \\ 2. Pengadilan Negeri Nganjuk
}

\begin{abstract}
ABSTRAK
Penelitian ini bertujuan memperoleh pemahaman tentang perlindungan hukumterhadap isteri yang menjadi korban tindakan kekerasan suami. Faktor Penyebab terjadinya kekerasan ini disebabkan karena faktor kepedulian keluarga dan lingkungan, faktor budaya, faktor penegakan hukum, faktor ekonomi, faktorkepribadian suami. Peranan petugas penegak hukum dalam melindungi hak-hak perempuan telah dimulai sejak ditemukannya kasus kekerasan ke petugas kepolisian hingga saat pemeriksaan di pengadilan. Diawali dari lembaga Kepolisian yang menerima pengaduan tentang adanya tindak kekerasan, untuk melindungi korban yang melaporkan kekerasan yang dialaminya. Setelah proses melapor, polisi membuat berkas perkara yang kemudian akan dilimpahkan ke kejaksaan. Kemudian kejaksaan akan membuat dakwaan dan tuntutan yang akhirnya akan diputus oleh hakim di Pengadilan. Dalam upaya memberikan perlindungan hukum terhadap isteri yang menjadi korban tindakan kekerasan suami ditemukan beberapa kendala. Kendala tersebut diantaranya disebabkan oleh faktor hukumnya sendiri, faktor petugas penegak hukum, faktor sarana dan fasilitas, faktor masyarakat, faktor budaya
\end{abstract}

Kata kunci : Kekerasan Dalam Rumah Tangga (KDRT), Korban, Perlindungan Hukum.

\section{A. PENDAHULUAN}

Rumah adalah tempat untuk membangun keluarga yang bahagia, harmonis dan sejahtera. Rumah tangga merupakan unit yang terkecil dari susunan kelompok masyarakat, rumah tangga juga merupakan sendi dasar dalam membina dan terwujudnya suatu negara. Indonesia sebagai negara yang berlandaskan pancasila yang didukung oleh umat beragama mustahil bisa terbentuk rumah tangga tanpa perkawinan. Karena perkawinan tidak lain adalah permulaan dari rumah tangga.

Ada tiga hal mengapa perkawinan itu menjadi penting. Petama: perkawinan adalah cara untuk ikhtiyar manusia melestarikan dan mengembangbiakan keturunanya dalam rangka melanjutkan kehidupan manusia di muka bumi. Kedua: perkawinan menjadi cara manusia menyalurkan hasrat seksual. Ketiga: perkawinan merupakan wahana rekreasi dan tempat orang menumpahkan keresahan hati dan membebaskan diri dari kesulitan hidup secara terbuka kepada pasanganya. Undang-Undang No. 1 Tahun 1974 tentang Perkawinan, perkawinan ialah ikatan lahir batin antara seorang pria dan wanita sebagai suami istri dengan tujuan membentuk keluarga (rumah tangga) yang bahagia dan kekal berdasarkan ketuhanan Yang Maha Esa. ${ }^{1}$

\footnotetext{
${ }^{1}$ Undang-Undang RI No. 1 tahun 1974, tentang Perkawinan, (Yogyakarta : Pustaka Widyatama, Cet. I, 2004), hal. 8
}

Selain itu dalam Pasal 33 UndangUndang No. 1 Tahun 1974 tentang Perkawinan mengatakan bahwa: "Antara suami istri mempunyai kewajiban untuk saling cintamencintai, hormat menghormati, setia dan memberi bantuan lahir batin yang satu kepada yang lain. Bahkan suami dan istri mempunyai kedudukan yang sama / seimbang dalam kehidupan berumah tangga dan pergaulan hidup di masyarakat serta berhak melakukan perbuatan hukum".2

Pasal 1 dan Pasal 33 Undang-Undang No. 1 Tahun 1974 tentang Perkawinan diartikan sebagai larangan adanya kekerasan dalam rumah tangga khususnya kekerasan oleh suami terhadap isteri, karena hal ini tidak sesuai dengan tujuan perkawinan serta hak dan kewajiban suami isteri. Dengan pengaturan hak dan kewajiban yang sama antara suami istri dalam rumah tangga, pergaulan masyarakat, dan dimuka hukum serta adanya kewajiban untuk saling mencintai menghormati, setia, dan saling memberi bantuan lahir batin maka UU Perkawinan bertujuan agar kehidupan antara suami istri akan terhindar dari perselisihan atau tindakan-tindakan fisik yang cenderung menyakiti dan membahayakan jiwa seseorang.3

\footnotetext{
2 Republik Indonesia, Undang-Undang Nomor 1 tahun 1974 tentang Perkawinan, Pasal 33

3 Rika Saraswati. Perempuan dan Penyelesaian Kekerasan dalam Rumah Tangga. (Bandung: PT Citra Aditya Bakti. 2006). Hal 2
} 
Indonesia sebenarnya telah memberi perlindungan terhadap korban kekerasan dalam rumah tangga, yaitu dengan Undang-Undang Nomor 23 tahun 2004 tentang Penghapusan Kekerasan Dalam Rumah Tangga (PKDRT), yang disahkan pada tanggal 22 September 2004. Disahkannya UU PKDRT terwujudlah law in book dan pengakuan dari pemerintah bahwa dulu KDRT sebagai skeleton in closet, kini menjadi tindak pidana atau urusan publik.4

$$
\text { Kejahatan kekerasan pada }
$$

hakekatnya adalah suatu perwujudan perilaku manusia. 5 Undang-Undang PKDRT menyebutkan bahwa Kekerasan dalam Rumah Tangga adalah setiap perbuatan terhadap seseorang terutama perempuan, yang berakibat timbulnya kesengsaraan atau penderitaan secara fisik, seksual, psikologis, dan/ atau penelantaran rumah tangga termasuk ancaman untuk melakukan perbuatan, pemaksaan, atau perampasan kemerdekaan secara melawan hukum dalam lingkup rumah tangga.6

Dengan demikian tindakan kekerasan yang dilakukan suami terhadap isteri perlu disikapi dan ditangani sampai tuntas agar isteri yang menjadi korban kekerasan dari suaminya mendapat perlindungan yang layak. Oleh karena itu akan dibahas dalam penelitian Jurnal Ilmiah ini mengenai perlindungan hukum terhadap isteri yang menjadi korban kekerasan dalam rumah tangga oleh suami.

Berdasarkan latar belakang dan lingkup permasalahan sebagaimana diuraikan diatas, maka dapat dirumuskan masalah dalam penelitian ini:

1. Faktor-faktor apakah yang menyebabkan terjadinya kekerasan dalam rumah tangga terhadap isteri yang dilakukan oleh suami ?

2. Bagaimana bentuk perlindungan hukum terhadap isteri yang menjadi korban tindakan kekerasan suami ?

3. Apa kendala yang dihadapi dalam upaya memberikan perlindungan hukum terhadap

\footnotetext{
${ }^{4}$ Sri Wahyuningsih, dkk. Persepsi dan Sikap Penegak Hukum Terhadap Penanganan

Kasus-Kasus Kekerasan dalam Rumah Tangga (KDRT) Sesuai dengan Undang-Undang Penghapusan KDRT Nomor 23 Tabun 2004 di Jawa Timur. Jurnal Ilimu-Ilmu Sosial (Social Sciences). (Malang : Lembaga Penelitian Universitas Brawijaya, Agustus 2006). hal 154.

5 Mardjono Reksodiputro, Kriminologi Dan Sistem Peradilan Pidana (Buku Kedua),(Jakarta : Pusat Pelayanan Keadilan dan Pengabdian Hukum (d/h Lembaga Kriminologi UI ),2007, hal 62.

${ }^{6}$ Republik Indonesia, Undang-undang No. 23 Tahun 2004 tentang Penghapusan Kekerasan Dalam Rumah Tangga, Pasal 1 ayat 1.
}

isteri yang menjadi korban tindakan kekerasan suami?

\section{B. HASIL PENELITIAN DAN PEMBAHASAN}

a. Faktor-Faktor Yang Menyebabkan Terjadinya Kekerasan Dalam Rumah Tangga Terhadap Isteri Yang Dilakukan Oleh Suami

Berdasarkan catatan tahunan Komisi Nasional Perempuan Tahun 2010 ada beberapa faktor yang menyebabkan terjadinya kekerasan terhadap isteri oleh suami ${ }^{7}$, antara lain :

1. Adanya ketimpangan hubungan antara lakilaki dan perempuan; baik di rumah tangga, maupun dalam kehidupan publik. Ketimpangan ini, yang memaksa perempuan dan laki-laki untuk mengambil peran-peran gender tertentu, yang pada akhirnya berujung pada perilaku kekerasan. Di keluarga misalnya, kebanyakan masyarakat percaya bahwa suami adalah pemimpin bahkan penguasa keluarga. Istri diposisikan seperti milik penuh suami, yang berada pada kontrol danpengawasannya. Sehingga apapun yang dilakukan istri, harus seizin dan sepengetahuan suami. Tidak sebaliknya. Ketika terjadi kesalahan sedikit saja dari istri dalam cara pandang suami, istri harus berhadapan dengan pengawasan dan pengontrolan dari suami. Suami merasa dituntut untuk mendidik istri dan mengembalikannya pada jalur yang benar, menurut cara pandang suami. Pengontrolan ini tidak sedikit, yang pada akhirnya menggunakan tindak kekerasan.

2. Timbulnya kekerasan dalam rumah tangga berkaitan dengan hubungan kekuasaan suami-istri dan diskriminasi jender di kalangan masyarakat. Kekuasaan dalam perkawinan diekspresikan dalam dua area. Kelompok pertama, dalam hal pengambilan keputusan dan kontrol atau pengaruh. Kelompok kedua, yang ada di belakang layar, seperti halnya ketegangan, konflik dan penganiayaan. Lebih lanjut dapat di katakan bahwa kekuasaan suami dalam perkawinan terjadi karena unsur-unsur kultural dimana terdapat norma-norma di dalam kebudayaan tertentu yang memberi pengaruh yang menguntungkan suami. Pembedaan peran dan posisi antara suami dan istri di dalam

\footnotetext{
${ }^{7}$ Catatan tahunan Komisi Nasional Perempuan
} Tahun 2010 
keluarga dan masyarakat di turunkan secara cultural dalam masyarakat pada setiap generasi, bahkan terkadang sampai di yakini sebagai ideology. Kekuasaan suami yang tinggi terhadap istri juga dipengaruhi oleh penguasaan suami dalam sistem keuangan, oleh karena itu suami menghabiskan waktu di sektor yang menghasilkan uang sementara istri mengurusi rumah tangga dan mengasuh anak, hal itu membuat masyarakat memandang pekerjaan suami lebih bernilai.

b. Perlindungan hukum terhadap isteri yang menjadi korban tindakan kekerasan suami.

Dibawah ini akan diuraikan beberapa istrumen hukum yang dapat melindungi isteri dari tindakan kekerasan yang dilakukan suaminya.

1. Kitab Undang-undang Hukum Pidana (KUHP)

Hukum pidana merupakan hukum publik yang memuat berbagai ketentuan-ketentuan tentang :

a. Aturan umum hukum pidana yang berhubungan dengan perbuatanperbuatan tertentu yang disertai ancaman sanksi berupa pidana bagi yang melanggar larangan tersebut.

b. Syarat-syarat tertentu yang harus dipenuhi bagi si pelanggar untuk dapat dijatuhi sanksi pidana.

c. Tindakan dan upaya-upaya yang boleh atau harus dilakukan oleh alat-alat negara dalam rangka menentukan dan melaksanakan pidana. ${ }^{8}$

2. Undang-undang Perkawinan (UU No. 1 Tahun 1974)

Selain hukum pidana, UU Perkawinan No. 1 Tahun 1974 dan peraturan sighat taklik talak sesunggungnya juga memberikan perlindungan hukum kepada kaum isteri yang mengalami kekerasan atau penganiayaan, dengan meminta kepada Pengadilan agar tidak serumah lagi karena keadaan yang membahayakan dirinya. Selanjutnya dalam Pasal 19 huruf d Peraturan Pemerintah No. 9 Tahun 1975 tentang Pelaksanaan UU No. 1 Tahun 1974 juga merupakan instrumen hukum perlindungan isteri terhadap tindakan kekerasan suami.

${ }^{8}$ Adami Chazawi, Pelajaran Hukum Pidana Bagian 1, (Jakarta : PT Raja Grafindo Persada, 2001), hal. 2
3. Undang-undang Penghapusan Kekerasan Dalam Rumah Tangga (UU No. 23 tahun 2004).

Bentuk-bentuk perlindungan hukum bagi isteri (sebagai yang termasuk dalm lingkup rumah tangga) yang mendapat tindakan kekerasan dalam Undang-undang Penghapusan Kekerasan Dalam Rumah Tangga (UU No. 23 tahun 2004) antara lain

a. Pasal 10, yang menyangkut hak-hak korban untuk mendapatkan :

1. Perlindungan dari pihak kelurga, kepolisian, kejaksaan, pengadilan, advocat, lembaga sosial atau pihak lainnya baik sementara maupun berdasarkan penetapan perintah perlindungan dari pengadilan,

2. Pelayanan kesehatan sesuai dengan kebutuhan medis

3. Penanganan secara khusus berkaitan dengan kerahasiaan korban,

4. Pendampingan oleh pekerja sosial dan bantuan hukum pada setiap tingkat roses pemeriksaan sesuai dengan ketentuan peraturan perundang-undangan,

5. Pelayanan bimbingan rohani.

b. Pasal 11 sampai dengan Pasal 15, berkaitan dengan kewajiban pemerintah dan masyarakat dalam upaya pencegahan kekeraasan dalam rumah tangga.

c. Pasal 16 sampai dengan Pasal 38 ; bentukbentuk perlindungan bagi korban kekerasan dalam rumah tangga yang diberikan oleh pihak kepolisian, tenaga kesehatan, pekerja sosial, relawan pendamping,pembimbing rohani, advokat, dan pengadilan.

d. Pasal 39 sampai dengan Pasal 43; hak korban untuk memperoleh pemulihan.

e. Pasal 44 sampai dengan Pasal 49; merupakan ketentuan pidana yang memberikan ancaman hukuman bagi pelaku kekerasan.

c. Kendala yang Dihadapi Dalam Upaya Memberikan Perlindungan Hukum Terhadap Isteri Yang Menjadi Korban Tindakan Kekerasan Suami.

Berikut hambatan yang terkait dengan substansi hukum yang ada, yaitu :

1. Payung kebijakan di bawah undang-undang, seperti peraturan-peraturan pelaksanaan dan alokasi anggaran negara, masih jauh dari memadai sehingga mempersulit penanganan 
yang sesuai dengan apa yang dimandatkan dalam Undang-Undang No. 23 Tahun 2004.

2. Ancaman hukum alternatif berupa kurungan atau denda, ancaman hukuman terlalu ringan untuk kasus tindak kejahatan/kekerasan yang terencana dan kasus yang korbannya meninggal, kekerasan seksual, dan psikis yang dilakukan suami terhadap isteri, merupakan delik aduan.

3. UU PKDRT lebih menitikberatkan proses penanganan hukum pidana dan penghukuman dari korban. Disatu sisi UU ini dapat menjadi alat untuk menjerakan pelaku dan represi terhadap siapa yang akan melakukan tindakan KDRT. Di sisi lain, penghukuman suami masih dianggap bukan jalan yang utama bagi korban, khusus nya isteri, yang mengalami KDRT. Ini pula yang menjadi alasan bagi korban untuk menarik pengaduannya di kepolisian.

4. Dari segi struktur bukum, kendala utama hadir dari lembaga Pengadilan Agama. Karena kewenangan Pengadilan Agama adalah untuk menyidangkan persoalan perdata/keluarga, hakim di Pengadilan Agama cenderung tidak menggunakan UUPKDRT dalam menangani kasus perceraian sekalipun kekerasan disebutkan sebagai penyebab gugatan cerai.

5. Sarana dan prasarana, khususnya berkaitan dengan ruang pelayanan, ruang sidang dan perlengkapannya, kurang memadai, sehingga mengganggu proses persidangan maupun penyelesaian kasus, keterbatasan dana, keterbatasan tenaga dan fasilitas lain yang khusus dialokasikan untuk menangani kasus Kekerasan dalam Rumah Tangga.

\section{KESIMPULAN}

Berdasarkan uraian diatas, dapat disimpulkan sebagai berikut:

\section{Faktor-Faktor Yang Menyebabkan} Terjadinya Kekerasan Dalam Rumah Tangga Terhadap Isteri Yang Dilakukan Oleh Suami

a. Adanya ketimpangan hubungan antara laki-laki dan perempuan; baik di rumah tangga, maupun dalam kehidupan publik.

b. Timbulnya kekerasan dalam rumah tangga berkaitan dengan hubungan kekuasaan suami-istri dan diskriminasi jender di kalangan masyarakat. Kekuasaan dalam perkawinan diekspresikan dalam dua area. Kelompok pertama, dalam hal pengambilan keputusan dan kontrol atau pengaruh. Kelompok kedua, yang ada di belakang layar, seperti halnya ketegangan, konflik dan penganiayaan.

2. Perlindungan hukum terhadap isteri yang menjadi korban tindakan kekerasan suami.

a. Kitab Undang-undang Hukum Pidana (KUHP)

b. Undang-undang Perkawinan (UU No. 1 Tahun 1974)

c. Undang-undang Penghapusan Kekerasan Dalam Rumah Tangga (UU No. 23 tahun 2004).

3. Kendala yang dihadapi dalam upaya memberikan perlindungan hukum terhadap isteri yang menjadi korban tindakan kekerasan suami.

a. Payung kebijakan di bawah undangundang

b. Ancaman hukum alternatif berupa kurungan atau denda.

c. UU PKDRT lebih menitikberatkan proses penanganan hukum pidana dan penghukuman dari korban.

d. Dari segi struktur bukum, kendala utama hadir dari lembaga Pengadilan Agama.

e. Sarana dan prasarana.

\section{DAFTAR PUSTAKA}

Adami Chazawi, Pelajaran Hukum Pidana Bagian 1, (Jakarta : PT Raja Grafindo Persada, 2001)

Catatan tahunan Komisi Nasional Perempuan Tahun 2010.

Kasus-Kasus Kekerasan dalam Rumah Tangga (KDRT) Sesuai dengan Undang-Undang Penghapusan KDRT Nomor 23 Tabun 2004 di Jawa Timur. Jurnal Ilimu-Ilmu Sosial (Social Sciences). (Malang : Lembaga Penelitian Universitas Brawijaya,. Agustus 2006).

Mardjono Reksodiputro, Kriminologi Dan Sistem Peradilan Pidana (Buku Kedua), (Jakarta : Pusat Pelayanan Keadilan dan Pengabdian Hukum (d/h Lembaga Kriminologi UI ),2007

Republik Indonesia, Undang-undang No. 23 Tahun 2004 tentang Penghapusan Kekerasan Dalam Rumah Tangga.

Republik Indonesia, Undang-Undang Nomor 1 tahun 1974 tentang Perkawinan

Rika Saraswati. Perempuan dan Penyelesaian Kekerasan dalam Rumah Tangga. (Bandung: PT Citra Aditya Bakti. 2006). 